\title{
Epidemiology in Latin America: an opportunity for a global dialogue
}

\section{Neil Pearce}

Until recently, most European, North American and Australasian epidemiologists knew Latin America as a region of the world that produced both great football teams and hazardous military dictatorships (although the North Americans may not have known much about the football teams). In addition, it was a region that we had to fly over the top of in order to meet each other in New York, London or Sydney. Few "Western" epidemiologists have been aware of the developments in epidemiology in Latin America in the last two decades, which have paralleled the return of democracy across the continent.

This situation is hopefully about to change with the staging of the XVIIIth International Epidemiological Association World Congress of Epidemiology in Porto Alegre, Brazil. This is only the third time that the Congress has been held in Latin America (after Cali, Colombia, in 1959 and San Juan, Puerto Rico, in 1977) and only the second time in the Southern hemisphere (after Sydney, Australia, in 1993). For many epidemiologists from outside Latin America, it will be a chance to catch up with the work that their colleagues in Europe, North America and Australasia are doing, albeit in a more interesting and exotic location and accompanied by caipirinha instead of lager. However, there are several reasons why the Congress can be a lot more than that and represents an opportunity that should not be missed.

First, there is a great deal that epidemiologists from "the West" can learn from their Latin American colleagues. ${ }^{1}$ Epidemiology in Latin America has a rich and relatively recent history, with impressive and rapid developments in epidemiology both as a scientific discipline and as a branch of public health with a firm commitment towards transforming the health of the population. ${ }^{2}$

Correspondence to: Professor N Pearce, Centre for Public Health Research, Massey University Wellington Campus, Private Box 756, Wellington, New Zealand; n.e.pearce@massey.ac.nz
This development has involved parallel and integrated developments in both the theory and the practice of epidemiology, with an emphasis on the social determination of disease, while incorporating recent technical and theoretical advances at the cellular and molecular levels in an interdisciplinary manner. While many of us in "the West" have been talking about restoring the population perspective to epidemiology, and re-integrating it into public health, our Latin American colleagues have been doing it. In this context, it should be emphasised that, if epidemiology is "the study of the distribution and determinants of health-related states or events in specified populations, and the application of this study to control of health problems", ${ }^{3}$ and if we recognise that the major burden of disease is currently occurring in nonWestern populations, then epidemiology in Latin America is part of the mainstream, not an "exotic" alternative.

Second, it is increasingly recognised that "Western" epidemiologists now have global responsibilities. ${ }^{1}$ The limited success of legislative measures in industrialised countries has led the tobacco industry to shift its promotional activities to developing countries so that more people are exposed to tobacco smoke than ever before. ${ }^{4}$ Similar shifts have occurred for some occupational carcinogens ${ }^{5}$ and for other occupational hazards. ${ }^{6}$ The global "achievement" of the public health movement has often been to move public health problems from rich countries to poor countries. Just as "the West" represents a minority of the world's population, but uses the majority of the resources, only about $10 \%$ of the world's health research funding is allocated to the $90 \%$ of the world's health problems that occur in non-Western populations.' However, it should be stressed that what is required is not that Western epidemiologists engage in "volunteerism" to enable the "benefits" of Western approaches to epidemiology to be shared by the nonWestern world. In contrast, Ebrahim and Davey $\mathrm{Smith}^{8}$ argue that the individualfocused methods of health promotion for coronary heart disease and stroke have had limited success in the West and that we are now "exporting our tired and failed models of health promotion to developing countries". This does not mean that there is nothing that nonWestern epidemiologists can learn from the West; clearly, there is a great deal, but what is needed is a dialogue rather than a monologue. ${ }^{1}$ With increasing globalisation, we are all in it together.

Third, there are some scientific questions that can best be answered by genuine international collaborations that benefit all the countries concerned. For example, studies of Westernisation and asthma, ${ }^{9}$ and the associated "hygiene hypothesis', ${ }^{10}$ cannot be addressed only by studies in Western countries where virtually everyone is exposed to a relatively "clean environment". It requires global comparisons to clearly show that the hygiene hypothesis is not an adequate or complete explanation for current asthma prevalence patterns and time trends. ${ }^{10}$

For these reasons, the globalisation of epidemiology is going to occur as inevitably as economic globalisation is occurring and, in both instances, the issue is what form that globalisation will take. Will we simply "export failure" through our "volunteerism" and our exporting of epidemiological methods developed specifically for studies of individual lifestyle risk factors in Western countries? Or will a truly global epidemiology develop to address the major global public health problems using appropriate methodology? Porto Alegre represents an important opportunity to continue the dialogue.

Acknowledgements: The Centre for Public Health Research is supported by a Programme Grant from the Health Research Council of New Zealand.

Competing interests: None declared.

Accepted 23 June 2008

J Epidemiol Community Health 2008;62:762-763. doi:10.1136/jech.2008.078659

\section{REFERENCES}

1. Pearce N. The globalization of epidemiology Int J Epidemiol 2004;33:1127-31.

2. Barreto ML. The globalization of epidemiology: critical thoughts from Latin America. Int J Epidemiol 2004:33:1132-7.

3. Last JM, ed. A dictionary of epidemiology. New York: Oxford University Press, 1988.

4. Barry M. The influence of the United-States tobacco industry on the health, economy, and environment of developing-countries. N Engl J Med 1991;324:917-20.

5. Pearce N, Matos E, Boffetta P, et al. Occupational exposures to carcinogens in developing countries. Ann Acad Med Singapore 1994;23:684-9.

6. Loewenson R. Epidemiology in the era of globalization: skills transfer or new skills? Int J Epidemiol 2004;33:1144-50. 
7. Global Forum for Health Research. The 10/90 report on health research 2001-2002. Geneva: Global Forum for Health Research, 2002.
8. Ebrahim S, Smith GD. Exporting failure? Coronary heart disease and stroke in developing countries. Int J Epidemiol 2001; 30:201-5.
9. Douwes J, Pearce N. Asthma and the westernization "package". Int J Epidemiol 2002;31:1098-102.

10. Douwes J, Pearce N. The end of the hygiene hypothesis? Int J Epidemiol 2008:37:570-2.

\section{"It was twenty years ago today..." - the beginning of the Brazilian National Health Care System}

This brief recollection aims to introduce the historical development of the Brazilian National Health Care System to a larger audience. $^{1}$

A military coup d'état in 1964 interrupted the fledgling democratic development in Brazil that began with the end of the Vargas dictatorship in 1945. Unsuccessful attempts to overthrow the new regime through guerilla warfare gave way, during the 1970s, to the slow reorganisation of civil society.

Health became a focal point for the convergence of progressive forces, especially in the postgraduate programmes in public health that began to flourish in the country. The confluence of those in academia, health managers and providers with affinity (if not affiliation) with the then clandestine leftwing parties crafted an alliance that became known as the sanitary reform movement (SRM). ${ }^{2}$

The health care model adopted by the military regime segregated the population into those who were formally employed and the "indigents", who got very little, if any, state-backed care. The organisation of health also divided prevention and treatment, and the systematics of financing and health care delivery was labelled by one of the leading figures of the SRM as "socializing the losses and privatizing the gains": funds were collected by the government through mandatory contributions, and the for-profit sector was the main beneficiary of such monies.

At the beginning of the 1980s, the ailing Brazilian economy forced changes in that model, still during military rule; ideas proposed by the SRM intelligentsia suddenly became viable, if for no other reason than the necessity of cutting costs. In 1982, the first free election for state governors since the coup brought key opposition figures to the helm in the main states; soon, the health departments of those states became active laboratories for the new ideas, proposing a health care system that was decentralised, universal and comprehensive and had ample popular participation in its management and control-the key principles defined by the SRM as the stepping stone for the desired national care system. Despite the political differences with the federal government, embryonic experiments in cooperation between different government levels began to take place.

The military regime collapsed without bloodshed in 1985; the democratic debate flourished in all areas, and a milestone was the realisation of the Eighth National Health Conference in 1986. Soon after that, in 1987, the newly elected parliament was assigned the task of drafting the new constitution. After two years of intense negotiation and widespread political debate, the new constitution was approved in 1988. The basic tenets proposed by the SRM were enshrined in it and, in particular, the principle that health is a right of the citizens and a duty of the state. The Sistema Único de Saúde (SUS), the Brazilian National Health Care System, was born.

Twenty years later, there is still a lot to be done; perpetually plagued by a lack of adequate resources and administrative discontinuity, with health indicators that are still far from what we would want them to be, the SUS has nevertheless made major contributions to the general quality of health of the Brazilian population in general, and particularly its less favoured portion. Furthermore, the political processes unleashed by the establishment of SUS have contributed, and still do, to increased democratic participation in the public policy arena.

\section{Kenneth Rochel de Camargo Jr}

Correspondence to: Associate Professor K Rochel de Camargo, Jr, R Afonso Pena, 141/402, Rio de Janeiro, RJ, 20270-244, Brazil; kenneth@uerj.br

Competing interests: None.

J Epidemiol Community Health 2008;62:763. doi:10.1136/jech.2008.079053

\section{REFERENCES}

1. Lobato L, Burlandy L. The context and process of health care reform in Brazil. In: Fleury S, Belmartino S, Baris E, eds. Reshaping health care in Latin America: a comparative analysis of health care reform in Argentina, Brazil, and Mexico. Ottawa: IDRC, 2000. http://www.idrc.ca/en/ev-35305-201-1-D0 TOPIC.html (accessed 18 June 2008).

2. Cordeiro H. 0 Instituto de Medicina Social e a luta pela reforma sanitária: contribuição à história do SUS. Physis—Rev Saúde Coletiva 2004;14:343-62. 


\section{Epidemiology in Latin America: an opportunity for a global dialogue}

Pearce, Neil

2008-09

http://hdl.handle.net/10179/9721

22/04/2023 - Downloaded from MASSEY RESEARCH ONLINE 